REPORTS OF MORPHOLOGY
$\begin{gathered}\text { Official Journal of the Scientific Society of Anatomists, } \\ \text { Histologists, Embryologists and Topographic Anatomists } \\ \text { of Ukraine } \\ \text { journal homepage: https://morphology-journal.com }\end{gathered}$

Variability of T-lymphocytes and macrophages composition in the urinary bladder under the influence of heavy metals salts, correction of their effect with vitamin $E$ and in the readaptation period

\title{
Sikora V.V.
}

Sumy State University, department of Pathological Anatomy, Sumy, Ukraine

\section{ARTICLE INFO}

Received: 20 November, 2017

Accepted: 12 January, 2018

UDC: $616.62-002-$

092.9:613.63:615.356:577.161.3

\section{CORRESPONDING AUTHOR}

e-mail: v.sikora@med.sumdu.edu.ua Sikora V.V.
In modern urology, it is important to study and understand the features of the development of various pathologies in the organs of the urinary system since the disturbances of the urodynamics is a widespread problem all over the world. Thus, the environment pollution caused by heavy metal salts has unpredictable consequences for the functioning of the urinary bladder. That is why the object of this study is to determine the features of the expression and the quantitative composition of $T$-cells and macrophages in the UB wall under the intake of the HMS and correction of their effect with vitamin $E$, as well as during the readaptation period. According to the experimental scenario, the experiment model was implemented by using male rats that were divided into six groups. The heavy metal salts mixture consisted of the most common potentially dangerous metals-microelements (zinc, cooper, iron, manganese, lead and chrome). Vitamin E was chosen as a corrector. To determine the quantitative composition of T-cells and macrophages the immunohistochemical identification by $C D 3$ and $C D 68$ antibodies was used. The main results are presented as $M \pm S D$, with the assessment of the differences and dependencies between the groups by using nonparametric Mann-WhitneyU testand Spearman's Rank Correlation Coefficient. We found that the number of CD3+ lymphocytes and CD68+ macrophages differed between the groups and depended on the experimental conditions. Thus, the results of our study demonstrate that the number of T-cells and macrophages in the bladder increases under the influence of heavy metals salts. The simultaneous intake of the pollutants and vitamin $E$ is accompanied by the decrease of expression intensity of the corresponding cells. When the intake of the heavy metals is canceled, the qualitative composition of the identified $C D 3$ and $C D 68$ cells gradually comes to the norm, but the speed of its reduction differs depending on the group of the readaptation. Discovered that the decrease of $T$-cells and macrophages in the groups with the use of vitamin $E$ was more approached to the control. Basedon the results of the immunohistochemical study, a strong correlation between an increased number of the expressed T-cells and macrophages was revealed in the urinary bladder during the whole period of the study that demonstrates the dependence of their activity.

Keywords: urinary bladder, heavy metals salts, T-lymphocytes, macrophages, vitamin E, readaptation.

\section{Introduction}

In modern urology, it is important to study and understand the features of the development of various pathologies in the organs of the urinary system since the disturbances of the urodynamics is a widespread problem all over the world [3, 4]. Nowadays the mechanisms of the pathogenesis of these processes are studied insufficiently that stipulates the awareness of the main causes of their occurrence [3].

Inflammation of the urinary bladder (UB) plays an important role in the urodynamics disturbance [10]. The pathology of this organ often accompanies various pathologies of the urogenital system and may be the first 
clinical manifestation of their lesions. There are various theories of the development of the inflammation in the UB, and this complicates the understanding of the details of its pathogenesis $[3,6,10]$. It is known that the inflammation of this organ occurs when the protective barriers both in the mucous membrane and in its walls are broken [3, 5, 10]. However, the nature of the disease and the symptoms may vary, depending on the provocative factors: factors of the modern lifestyle (smoking, alcohol, chronic stress), the influence of the pollutants (anthropogenic pollution), the presence of the pathogenic microorganisms (Escherichia coli, Clostridium botulinum, etc.) and pathological processes in the UB wall (innervation disorders, cystitis and cancer) [3, 6, 7, 10, 11].

The number of the reports on the connection between the heavy metal salts (HMS) and ecologically caused diseases has increased significantly [8]. It is caused by the increased urbanization of the population and increased number of the dangerous human-made emissions followed by the environmental pollution and ecological imbalance. The effect of the heavy metals (HM) is unpredictable due to the variety of their combinations and concentrations in the polluted regions of the world $[5,8,14]$.

The object of the study is to determine the features of the expression and the quantitative composition of T-cells and macrophages in the UB wall under the intake of the HMS and correction of their effect with vitamin E, as well as during the readaptation period.

\section{Materials and methods}

The experiment model was implemented by using white male rats $(n=84)$ with a detailed UB research on the 30,90 , 120 and 180 day of the study. Thus, according to the experimental scenario, laboratory animals were divided into six groups: I - control group; II - rats that received water with the HMS mixture during 30 and 90 days; III - rats that received water with $\mathrm{HM}$ during the corrective therapy for 30 and 90 days; IV - animals on the 30 (120) and 90 (180) day after discontinuation of $\mathrm{HM}$ using; $\mathrm{V}$ - animals that received vitamin E within 30 (120) and 90 (180) days of readaptation after discontinuation of HMS using; VI - animals that received corrective therapy during 30 (120) and 90 (180) days after long-term $\mathrm{HM}+$ vitamin $\mathrm{E}$ influence. The animals were taken out of the experiment in certain periods by the decapitation after narcosis with the further UB removal. The animals were kept in the vivarium with the temperature, humidity, and day/night mode control and free access to water and food. All studies and control of the animals were conducted in accordance with the rules for the use of the animals in the experiments, adopted by the "European Convention for the Protection of Vertebrate Animals Used for Experimental and other Scientific Purposes" (Strasbourg, 1986), "General Ethical Principles of Animal Experiments", adopted by the First National Congress On Bioethics (Kyiv, 2001), "Ethical Principles and Guidelines for Experiments on Animals: 3rd Edition" (Switzerland 2005) and the Law of Ukraine "On the Protection of Animals from Cruel Treatment" (2006).
The HMS mixture consisted of the following potentially dangerous metals and microelements that circulate in the environment: zinc ( $\mathrm{ZnSO} 4 \times 7 \mathrm{H} 2 \mathrm{O})$ - $5 \mathrm{mg} / \mathrm{l}$, cooper (CuSO4x5H2O) - $1 \mathrm{mg} / \mathrm{l}$, iron (FeSO4) - $10 \mathrm{mg} / \mathrm{l}$, manganese (MnSO4x5H2O) - $0.1 \mathrm{mg} / \mathrm{l}$, lead (Pb(NO3)2) - $0.1 \mathrm{mg} / \mathrm{l}$, chrome (K2Cr2O7) - $0.1 \mathrm{mg} / \mathrm{l}$. Vitamin E (alpha-tocopherol acetate (Vitamin E) was chosen as a corrector, with the calculated average dose for the rats $(9.1 \mathrm{mg} / \mathrm{kg})$.

After removal, the UBs were fixed in $10 \%$ formalin solution, dehydrated in graded ethanol and embedded in paraffin. The series of sections (the thickness 3-5 $\mu \mathrm{m}$ ) were obtained on a rotary microtome. Visualization of the immunohistochemistry of the receptors was performed by UltraVision Quanto Detection System HRP DAB Cromogen (Thermo scientific, USA).

To determine the properties of T-cells and macrophages, as well as their quantitative composition, the immunohistochemical identification by using monoclonal antibodies of cluster differentiation CD3 (dilution 1:150) and CD68 (dilution 1:200).

The light and optical study of the UB was carried out by using "Carl Zeiss Primo Star" microscope with "Zeiss AxioCam ERs 5s" digital camera and "ZEN 2 (blue edition)" software. The obtained data was calculated in Graph Pad® 6.0. The digital results are presented as $\mathrm{M} \pm S D$, with the assessment of the differences and dependencies between the groups by using nonparametric Mann-Whitney $U$ test and Spearman's Rank Correlation Coefficient. $p<0.05$ is the statistically significant value.

\section{Results}

The immunohistochemical study of the control group revealed the single CD3- and CD68-positive expression with membrane and cytoplasm patterns of the expression (Fig. 1 -A). Identified T-cells (1.933 \pm 0.710$)$ and tissue-specific macrophages $(2.635 \pm 1.030)$ were localized namely in the stromal components of the UB.

In the animals from the II group that were given the HMS during 30 and 90 days, the number of positive expressed Tcells increased up to $18.42 \pm 4.78$ and $12.75 \pm 4.12(p<0.01)$ (Fig. 1-B) cells in the field. The study of the macrophage generation revealed the increased activity of CD-68 positive cells due to the mixed cellular inflammatory infiltration. Herewith, the number of the macrophages increased with the extension of the experiment on the $30^{\text {th }}$ day $(14.55 \pm 5.19$, $\mathrm{p}<0.05)$ and $90^{\text {th }}$ day $(19.58 \pm 6.89, \mathrm{p}<0.05)$ (Fig. 1-B). Diffuse or lesion localized CD3 positive cells were localized mainly around the vessels and in the fields of the inflammatory infiltrates of the stroma, directed towards the epithelium.

At the same time, on the $30^{\text {th }}$ day of the correction of the influence of the exogenous pollutants with vitamin E (III group), the number of CD3 and CD68 cells increased up to $16.38 \pm 4.30$ and $11.57 \pm 4.06(p<0.01)$ in comparison with the control group. However, on the $90^{\text {th }}$ day of the study the smooth reduction of the expression of the positive lymphocytes up to $10.58 \pm 3.55(p<0.01)$ as well as increased 
I
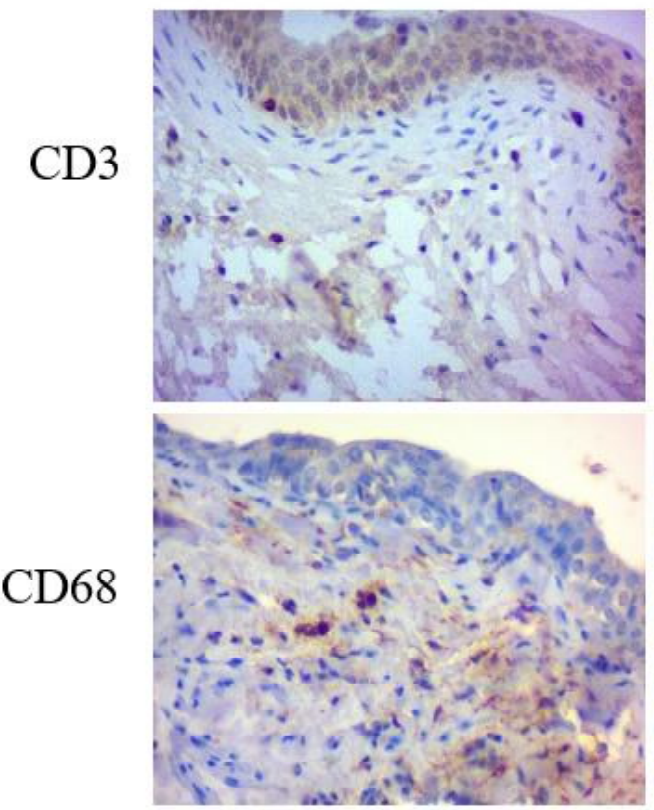

II
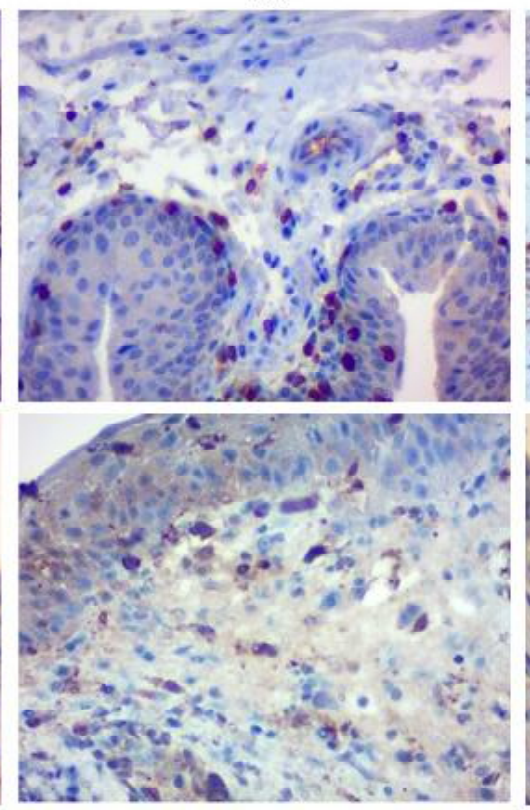

III
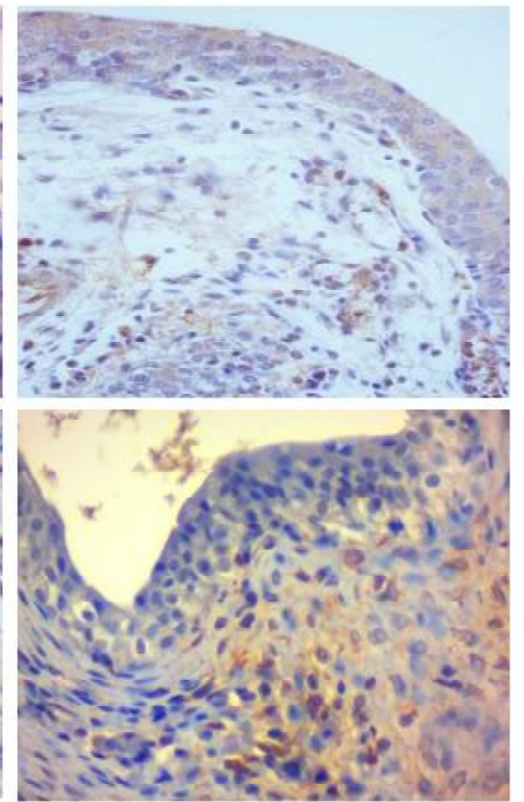

Fig. 1. The UB wall of experimental animals. I - control group; Il group - laboratory animals that consumed water saturated of HMS during 90 days; III group - rats that received water with a HMS combination and vit. E within 90 days. Immunohistochemical study of CD3 and CD68 receptors. Magnification. $\times 400$.

number of macrophages up to $15.42 \pm 5.35(p<0.01)$ was observed (Fig. 1-C).

With the extension of the experiment, on the $30^{\text {th }}$ day of the readaptation the decreased number of the expressed Tcells $(10.35 \pm 3.49$ vs $8.567 \pm 3.140$ vs $6.883 \pm 2.510, p<0.01$ ) in the stromal components of the UB was observed in IV, $V$ and VI groups. It should be mentioned that the activity of Tcells markers and their numerical difference in comparison with the control group continued to decrease and accounted $6.417 \pm 2.460(p<0.01)$ vs $3.650 \pm 1.210(p>0.05)$ vs $2.750 \pm 0.950(p>0.05)$, after 3 months of the rehabilitation.

The comparison of the phagocytic activity of the tissue macrophages by the identification with the antibodies to CD68+ cells on 120 and 180 days of the experiment showed the variations in their levels. Thus, the number of the macrophages in the UB wall depended on the studied group, namely: $15.80 \pm 5.06$ and $9.750 \pm 3.430(p<0.01)$ - in the group after the HMS intakewas canceled; $11.55 \pm 3.84$ and $6.217 \pm 2.5(p<0.01)$ - with the use of the corrector during the entire rehabilitation period; $8.730 \pm 3.020$ and $4.283 \pm 2.230(p<0.01)$ - with the extension of the vitamin $E$ intake during the readaptation.

Based on the results of the immunohistochemical study, a strong correlation $(r=0.76, p<0.01)$ between an increased number of the expressed T-cells and macrophages was revealed in the UB wall of all groups. These correlation indices are due to the long-term effects of HMS and shows the activity dependence of CD3 and CD68 positive cells.

\section{Discussion}

The activity of the elements of the immune system plays an important role in the pathogenesis of many diseases.
The role of the cells of the immune system in the local immune reactions, both during the inflammation and neoplasia is described in details $[2,13]$. It is reported about the correlation between the composition of the immune microenvironment and the course of the disease or the development of the tumors in people who live in the polluted areas [12]. Thus, it is important to study the composition of the inflammatory infiltrate to predict the behavior of the immune system. Moreover, the modern markers of the cluster differentiation help accurately determine the cellular elements of the inflammatory infiltrate $[9,12]$, namely, T-cells (CD3) and macrophages (CD68).

It is known that the effect of the HMS on the body results in the deep histological and immunohistochemical changes in the UB and disorders in its structural homeostasis [11]. In this study, we revealed that the inflammatory cells of the different sub-population accumulate in the stromal components of the UB due to the long-term influence of the HMS mixture. Herewith, their activity increased when the experiment was extended and significantly exceeded the control indicators. It is considered to be the normal response of the body to the stress factor, but the composition of the inflammatory infiltration may vary depending on the conditions and period of the inflammation [2, 3, 7, 9]. On the other hand the immune reaction in the group with the corrector was less intensive that is demonstrated by the decrease of the generation of T-cells and macrophages. It can be explained by that fact that vitamin $E$ has the effective protective effect from the HMS that is also proved by the less expressed morphological changes, demonstrated in the previous studies [1]. 
When the influence of the extreme factors on the body was canceled, the qualitative decrease of CD3 and CD68 positive expressed cells in the lesion was stated in all groups of the readaptation. It should be mentioned that the decrease of T-cells and macrophages activity in the groups with the use of vitamin E was more approached to the control.

The obtained results demonstrate that the immunohistochemical reaction with the selected antibodies was individual in each case. Thus, the number of CD3+ lymphocytes and CD68+ macrophages differed between the groups and depended on the experimental conditions. The long-term presence of CD68-positive cells in the lesions of the inflammatory infiltrates may be caused by the maintenance of the enhanced phagocytosis after the influence of the simulated microelementosis. Also, a strong

\section{References}

[1] Romaniuk, A., Sikora, V., Lyndin, M., Budko, H., \& Piddubnyi, A. (2016). The histological changes in the urinary bladder caused by simulated subacute influence of heavy metal salts. Bulletin of Biology and Medicine, 2(129), 80-83.

[2] Abraham, S.N., \& Miao, Y. (2015). The nature of immune responses to urinary tract infections. Nat. Rev. Immunol., 15(10), 655-663. doi: 10.1038/nri3887.

[3] Foxman, B. (2014). Urinary tract infection syndromes: occurrence, recurrence, bacteriology, risk factors, and disease burden. Infect. Dis. Clin. North Am., 28(1), 1-13. do: 10.1016/ j.idc.2013.09.003.

[4] Heydari, F., Rezadoust, B., Abbaszade, S., Afrouz, E., \& Ghadian, A. (2016) The Value of Urodynamic Study for Diagnosing the Causes of Lower Urinary Tract Symptoms in Male Patients: A Study From Iran. Nephrourol. Mon., 8(4): e34342. do: 10.5812/numonthly.34342.

[5] Jaishankar, M., Tseten, T., \& Anbalagan, N. (2014). Toxicity, mechanism and health effects of some heavy metals. Interdiscip. Toxicol., 7(2), 60-72.

[6] Keay, S. K., Birder, L. A., \& Chai, T. C. (2014). Evidence for Bladder Urothelial Pathophysiology in Functional Bladder Disorders. Biomed. Res. Int. do: 10.1155/2014/ 865463

[7] Kullmann, F. A. (2017). A new player in interstitial cystitis/ bladder pain syndrome: platelet-activating factor - PAF and its connection to smoking. Physiol. Rep., 5(7): e13235. do: 10.14814/phy2.13235

[8] Landrigan, P. J., Sly, J.L., Ruchirawat, M., Silva, E. R., Huo, X., Diaz-Barriga, F., ... Sly, P. D. (2016). Health Consequences of Environmental Exposures: Changing unidirectional correlation between the increased generation of the studied immune cells was observed. Taking into account the obtained results it is planned to study the correlation between the heavy metals accumulation and composition of the immune response.

\section{Conclusions}

The number of T-cells and macrophages in the UB wall increases under the influence of heavy metals salts. The simultaneous intake of the pollutants and vitamin $E$ is accompanied by the decrease of expression intensity of the corresponding cells. When the intake of the heavy metals is canceled, the qualitative composition of the identified CD3 and CD68 cells gradually comes to the norm, but the speed of its reduction differs depending on the group of the readaptation.

Global Patterns of Exposure and Disease. Ann. Glob. Health, 82(1), 10-19. do: 10.1016/j.aogh.2016.01.005.

[9] Liu, Y., Yang, W., Zhao, L., Liang, Z., Shen, W., Hou, Q., ... Ying S. (2016). Immune analysis of expression of IL-17 relative ligands and their receptors in bladder cancer: comparison with polyp and cystitis. BMCImmunol., 17, 36. do: 10.1186/s12865-016-0174-8.

[10] Lopez-Beltran, A., Montironi, R., \& Cheng, L. (2016). Pathology of the Urinary Bladder: An Algorithmic Approach. Cambridge University Press.

[11] Romaniuk, A., Sikora, V., Lyndin, M., Smiyanov, V., Sikora, V., Lyndina, Yu., ... Korobchanska, A. (2017). The features of morphological changes in the urinary bladder under combined effect of heavy metal salts. Interv. Med. Appl. Sci., 9(2). do: 10.1556/1646.9.2017.2.09.

[12] Sjodahl, G., Lovgren, K., Lauss, M., Chebil, G., Patschan, O., Gudjonsson, S., ... Hघglund, M4. (2014). Infiltration of $\mathrm{CD}^{+}$and $\mathrm{CD}^{+} 8^{+}$cells in bladder cancer is subtype specific and affects the outcome of patients with muscle-invasive tumors. Urol. Oncol., 32(6), 791-797. do: 10.1016/ j.urolonc.2014.02.007.

[13] Sui, X., Lei, L., Chen, L., Xie, T., \& Li, X. (2017). Inflammatory microenvironment in the initiation and progression of bladder cancer. Oncotarget, 54(8), 93279-93294. do: 10.18632/ oncotarget.21565.

[14] Wan, D., Han, Z., Yang, J., Yang, G., \& Liu, X. (2016). Heavy Metal Pollution in Settled DustAssociated with Different Urban Functional Areas in a Heavily Air-Polluted City in North China. Int. J. Environ. Res. Public. Health, 13(11), 1119. do: 10.3390/ijerph13111119.

\section{ВАРІАБЕЛЬНІСТЬ СКЛАДУ Т-ЛІМФОЦИТІВ ТА МАКРОФАГІВ У СЕЧОВОМУ МІХУРІ ЗА УМОВ ВПЛИВУ} СОЛЕЙ ВАЖКИХ МЕТАЛІВ, КОРЕКЦІЇ ЇХ ДІЇ ВІТАМІНОМ Е ТА У ПЕРІОД РЕАДАПТАЦІЇ

\section{Сікора В.В.}

Важливим питанням сучасної урології є вивчення та розуміння особливостей розвитку різноманітних патологій органів сечовидільної системи, так як порушення уродинаміки є широко розповсюдженою проблемою у різних країнах світі. Так, забруднення навколишнього середовища солями важких металів несе за собою непередбачувані наслідки на фукціонування сечового міхура. Саме тому метою цього дослідження стало встановлення особливостей експресії та кількісного складу Тлімфоцитів і макрофагів у стінці СМ за умов вживання солей важких металів та корекції їх дії вітаміном Е, а також у період реадаптації. Згідно з експериментальним сценарієм модель експерименту була реалізована за допомогою самців щурів, які були розділені на шість груп. До суміші солей важких металів ввійшли найпоширеніші потенційно небезпечні металимікроелементи (цинк, мідь, залізо, марганець, свинець і хром). В якості коректора було обрано вітамін Е. Для визначення кількісного складу Т-клітин та макрофагів була використана імуногістохімічна ідентифікація антитілами СDЗ та СD68. Основні результати представлені як $M \pm S D$, з оцінкою відмінностей та залежності між групами за допомогою непараметричного тесту Манн-Уітні U та коефіцієнта кореляції Спірмена. Ми виявили, що кількість CDЗ+ -лімфоцитів та макрофагів CD68+ відрізнялася 
між групами і залежала від експериментальних умов. Так, результати нашого дослідження демонструють, що за умов дії солей важких металів відбувається зростання кількості Т-лімфоцитів та макрофагів у стінці органа. Одночасне вживання полютантів та вітаміну Е супроводжується значно меншою інтенсивністю експресії відповідних клітин. Після відміни вживання важких металів кількісний склад ідентифікованих CDЗ та CD68 клітин поступово наближається до норми, однак швидкість їх зменшення відрізняється між серіями реадаптації. На підставі результатів імуногістохімічного дослідження встановлено сильні кореляційні зв'язки між зростанням кількості експресованих Т-лімфоцитів і макрофагів у сечовому міхурі протягом усього дослідження, що демонструє залежність ї активності.

Ключові слова: сечовий міхур, солі важких металів, Т-лімфоцити, макрофаги, вітамін Е, реадаптація.

\section{ВАРИАБЕЛЬНОСТЬ СОСТАВА Т-ЛИМФОЦИТОВ И МАКРОФАГОВ В МОЧЕВОМ ПУЗЫРЕ ПРИ ВОЗДЕЙСТВИИ СОЛЕЙ ТЯЖЕЛЫХ МЕТАЛЛОВ, КОРРЕКЦИИ ИХ ДЕЙСТВИЯ ВИТАМИНОМ Е И В ПЕРИОД РЕАДАПТАЦИИ \\ Сикора В.В.}

Важным вопросом современной урологии является изучение и понимание особенностей развития различных патологий органов мочевыделительной системы, так как нарушение уродинамики является широко распространенной проблемой в разных странах мире. Так, загрязнение окружающей среды солями тяжелых металлов влечет за собой непредсказуемые последствия на фукционування мочевого пузыря. Именно поэтому целью данного исследования стало установление особенностей экспрессии и количественного состава Т-лимфоцитов и макрофагов в стенке мочевого пузыря при условиях употребления солей тяжелых металлов и коррекции их действия витамином Е, а также в период реадаптации. Согласно экспериментальным сценарию модель эксперимента была реализована с помощью самцов крыс, которые были разделены на шесть групп. В смесь солей тяжелых металлов вошли самые распространенные потенциально опасные металлымикроэлементы (цинк, медь, железо, марганец, свинец и хром). В качестве корректора был избран витамин Е. Для определения количественного состава Т-клеток и макрофагов была использована иммуногистохимическая идентификация

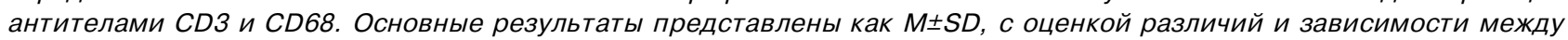
группами с помощью непараметрического теста Манн-Уитни U и коэффициента корреляции Спирмена. Мы обнаружили, что количество CD3+ лимфоцитов и макрофагов CD68+ отличалось между группами и зависило от экспериментальных условий. Так, результаты нашего исследования показывают, что в условиях влияния солей тяжелых металлов происходит рост числа Т-лимфоцитов и макрофагов в стенке органа. Одновременный прием поллютантов и витамина Е сопровождается значительно меньшей интенсивностью экспрессии соответствующих клеток. После отмены употребления тяжелых металлов количественный состав идентифицированных CD3 и CD68 клеток постепенно приближается к норме, однако скорость их уменьшения отличается между сериями реадаптации. На основании результатов иммуногистохимического исследования установлено сильные корреляционные связи между ростом количества экспрессированных Т-лимфоцитов и макрофагов в мочевом пузыре в течение всего исследования, что демонстрирует зависимость их активности.

Ключевые слова: мочевой пузырь, соли тяжелых металлов, Т-лимфоциты, макрофаги, витамин Е, реадаптация. 